\section{Fauna of Protected Areas - 26: PLANT AND SOIL NEMATODES FROM RANTHAMBHORE NATIONAL PARK, RAJASTHAN, INDIA}

\section{Padma Bohra and Qaiser H. Baqri}

Desert Regional Station, Zoological Survey of India, Jhalamand, Jodhpur, Rajasthan 342005, India

The knowledge on invertebrate fauna of Ranthambhore National Park (RNP) is meagre. Nematodes are found in all kinds of habitats. Several groups of nematodes inhabit soil, some are plant parasites others are predacious, while a large number of species are free living microphages. Each species plays a significant role in the ecosystem it inhabits. Baqri and Bohra (2003) have already published a paper reporting (Prothornenema capitatum \& Latocephalus conicaudatus) one new genus and two new species from RNP. The present paper reports the species of plant and soil nematodes from soil samples collected by ZSI survey parties of Desert Regional Station, Jodhpur during 1999-2003 from RNP.

Study Area: Ranthambhore National Park is famous for its natural heritage and rich biodiversity including tigers. The total area of RNP is $1334.64 \mathrm{~km}^{2}$. Popularly known as the Ranthambhore Tiger Reserve, it is situated in the south eastern part of Rajasthan. RNP is in Sawai Madhopur district stretching northeast of Sawai Madhopur town $\left(76^{0} 23^{\prime}-76^{0} 39^{\prime} \mathrm{E} \& 25^{\circ} 84^{\prime}-\right.$ $\left.26^{0} 12^{\prime} \mathrm{N}\right)$.

Soil samples were collected and nematodes were fixed in hot $4 \%$ formalin and mounted in anhydrous glycerine. All the specimens included in the present study have been deposited and registered in National Zoological Collection of Zoological Survey of India, Jodhpur.

The analysis yielded 23 species of plant and soil nematodes belonging to 21 genera of 12 families under four orders, viz., Tylenchida, Aphelenchida, Dorylaimida, and Mononchida. The results of the present study shows that great diversity of plant soil nematodes exist in Ranthambhore National Park. Among the recorded species, Longidorus pisi, Xiphinema orbum, Tylencholaimus paracassus and Aqatides aquaticus are being recorded for the first time from Rajasthan.

\section{REFERENCES}

Baqri, Q.H. and P. Bohra (2003). Prothornenema gen. n. and four new species of Dorylaimoidea (Nematoda: Dorylaimida) from India. International Journal of Nematology 13(2): 185-194.

Jairajpuri, M.S. and W. Ahmad (1992). Dorylaimida: free living, predaceous and plant parasitic nematodes. Oxford \& IBH Publishing Co. Pvt. Ltd., at New Delhi, 458pp.

Siddiqi, M.R. (2000). Tylenchida: Parasites of Plants and Insects. Published by CABI Publishing CAB International, Willingford, Oxon, OX 108DE, U.K., 833pp.
List of plant and soil nematode species recorded from Ranthambhore National Park.

Tylenchida: Hoplomaimidae

Hoplolaimus indicus Sher, 1963

Aphelenchida: Aphelenchidae

Aphelenchus avenae Bastian, 1865

Dorylaimida: Dorylaimidae

Laimydorus baldus Baqri \& Jana, 1982

Mesodorylaimus mesonyctius (Kreis, 1930)

Prothornenema capitatum Baqri \& Bohra, 2003

Sicaguttur sartum Siddiqi, 1971

Thornenema mauritianum (Williams, 1959)

\section{Aporcelaimidae}

Aporcelaimellus heynsi Baqri \& Jairajpuri, 1968

\section{Qudsianematidae}

Discolaimium mukhtarpuriense Baqri \& Jairajpuri, 1969

Discolaimoides bulbiferus (Cobb, 1906)

Discolaimus major Thorne, 1939

Ecumenicus monohystera (De Man, 1880)

Eudorylaimus chauhani (Baqri \& Khera, 1975)

Latocephalus conicaudatus Baqri \& Bohra, 2003

Nordiidae

Kochinema caudatum Baqri \& Bohra, 2001

Kochinema farodai Baqri \& Bohra, 2001

Longidoridae

Longidorus pisi Edward, Mishra \& Singh, 1964

Xiphinematidae

Xiphinema orbum Siddiqi, 1963

Tylencholaimidae

Tylencholaimus paracassus Monteiro, 1970

Leptonchidae

Leptonchus granulosus Cobb, 1935

Nygolaimidae

Aquatides aquaticus (Thorne, 1930)

Mononchida: Mononchidae

Mylonchulus minor (Cobb, 1893)

\section{ACKNOWLedGements}

Authors are thankful to Dr. J.R.B. Alfred, Director, Zoological Survey of India, Kolkata and Dr. N.S. Rathore, Joint Director, Desert Regional Station, Zoological Survey of India, Jodhpur for providing facilities. 